\title{
Penerapan Hand Hygiene Perawat di Ruang Rawat Inap Rumah Sakit
}

\section{Application of Nurse's Hand Hygiene in Hospital's Inpatient units}

\author{
Elies Ernawati ${ }^{1}$, Asih Tri $R^{2}$, Satra Wiyanto ${ }^{3}$ \\ ${ }^{1}$ Rumah Sakit Islam Hasanah Muhammadiyah Mojokerto \\ ${ }^{2}$ Dinas Kesehatan Kota Malang \\ ${ }^{3}$ RSI Aisyiyah Malang
}

\begin{abstract}
ABSTRAK
Hand hygiene adalah mencuci tangan menggunakan antiseptik pencuci tangan. Perilaku hand hygiene perawat merupakan salah satu faktor yang mempunyai pengaruh besar terhadap kesehatan perawat dan pasien dalam pencegahan terjadinya infeksi nosokomial. Studi bertujuan mengetahui gambaran tingkat kepatuhan perawat di ruang rawat inap Rumah Sakit " $X$ " di Malang dalam penerapan lima momen hand hygiene, mengidentifikasi faktor potensial yang berhubungan dengan hand hygiene tersebut. Studi observasional jumlah subjek sebesar 54 orang. Teknik pengambilan sampel dengan proportional stratified random sampling. Penentuan akar masalah menggunakan diagram fishbone. Pemilihan solusi dilakukan melalui pendekatan Urgency Seriousness Growth. Kepatuhan hand hygiene perawat ruang rawat inap rumah sakit masih rendah (35\%). Angka kepatuhan yang tinggi ditemukan pada momen sesudah kontak atau melakukan tindakan sedangkan kepatuhan cuci tangan sebelum kontak sangat rendah bahkan nol pada momen sebelum kontak dengan pasien. Analisis akar masalah menunjukkan faktor pengetahuan dan penguatan monitoring dalam bentuk audit, media pengingat, tidak adanya mekanisme sangsi dan penghargaan merupakan determinan kepatuhan hand hygiene.
\end{abstract}

Kata Kunci: Hand hygiene, kepatuhan, perawat

\section{ABSTRACT}

Hand hygiene is washing hands with antiseptic hand wash. Nurses' hand hygiene behavior is one of the factors that have a major influence on the health of nurses and patients in the prevention of nosocomial infection. This study aims to reveal the degree of nurses' compliance in the inpatient unit of " $X$ " hospital in Malang in the application of the five moments of hand hygiene and to identify the potential factors associated with the hand hygiene. Observational study subjects were 54 people. Sampling technique was with proportional stratified random sampling. Determination of the root of the problem was by using a fishbone diagram. The solution selection was done through an approach of Seriousness Growth Urgency. Hand hygiene compliance of nurses on inpatient unit is still low (35\%). A high rate of compliance was found at the moment after contact or take action while hand washing compliance before contact is very low, even zero at the moment before contact with the patient. Root cause analysis showed knowledge factors and monitoring strengthening in the form of audit, media reminders, the absence of sanction and reward mechanisms are determinants of hand hygiene compliance.

Keywords: Compliance, hand hygiene, nurses

Jurnal Kedokteran Brawijaya, Vol. 28, Suplemen No. 1, 2014: Elies Ernawati. Rumah Sakit Islam Hasanah Muhammadiyah Mojokerto, Jl. HOS Cokroaminoto 26-28 Jagalan Magersari Tel. (0321)321635Email: elies.nasya@gmail.com 


\section{PENDAHULUAN}

Masyarakat yang menerima pelayanan kesehatan, tenaga kesehatan dan pengunjung di rumah sakit dihadapkan pada risiko terjadinya infeksi atau infeksi nosokomial yaitu infeksi yang diperoleh di rumah sakit, baik karena perawatan atau datang berkunjung ke rumah sakit (1). Data menunjukkan tingginya angka infeksi nosokomial baik di dunia maupun Indonesia. Dari data surveilans WHO dinyatakan bahwa angka kejadiannya sebesar $5 \%$ pertahun (2).

Mencuci tangan telah dianggap sebagai salah satu tindakan terpenting untuk mengurangi penularan mikroorganisme dan mencegah infeksi selama lebih dari 150 tahun. Penelitian Semmelweis dan banyak penelitian lainnya memperlihatkan bahwa penularan penyakit menular dari pasien ke pasien mungkin terjadi melalui tangan petugas kesehatan. Menurut Boyce, Larson menjaga kebersihan tangan dengan baik dapat mencegah penularan mikroorganisme dan menurunkan frekuensi infeksi nosokomial (1).

Hand hygiene adalah istilah yang digunakan untuk mencuci tangan menggunakan antiseptik pencuci tangan. Pada tahun 2009, WHO mencetuskan global patient safety challenge dengan clean care is safe care, yaitu merumuskan inovasi strategi penerapan hand hygiene untuk petugas kesehatan dengan My five moments for hand hygiene (3), yaitu melakukan cuci tangan sebelum bersentuhan dengan pasien, sebelum melakukan prosedur bersih dan steril, setelah bersentuhan dengan cairan tubuh pasien, setelah bersentuhan dengan pasien, setelah bersentuhan dengan lingkungan sekitar pasien

Sebuah penelitian pada 40 rumah sakit melaporkan kepatuhan tenaga kesehatan yang melakukan hand hygiene sebelum dan setelah ke pasien bervariasi antara $24 \%$ sampai $89 \%$ (rata-rata $56,6 \%$ ). Penelitian ini dilakukan setelah dipromosikannya program WHO dalam pengendalian infeksi. Menurut data Riset Kesehatan Dasar tahun 2007, prevalensi nasional perilaku benar dalam cuci tangan adalah 23,2\%8 (3).

Dari studi pendahuluan didapatkan data beberapa penyakit infeksi yaitu Dengue Hemoraghic Fever, Gastroenteritis, Typhus Abdominalis, Tuberculosis, termasuk dalam diagnosa sepuluh penyakit terbanyak pasien rawat inap RS. Hasil kegiatan tim Panitia Pengendalian Infeksi Rumah Sakit (PPIRS) menunjukkan bahwa angka infeksi yang ada hanya terjadi di ruang rawat inap, sedang ruang lain adalah nol. Hasil kultur specimen pasien rawat inap didapatkan mikroorganisme terbanyak adalah Acinobachter Baumanii dan Escherichia Coli yang merupakan kuman terbanyak terdapat pada tangan manusia. Pentingnya melakukan kebersihan tangan yang baik dan benar sebagai pencegahan utama infeksi nosokomial dan penyebaran mikroorganisme multi resisten di rumah sakit. Hasil sidak tim PPIRS penerapan hand hygiene petugas kurang memuaskan.

Hasil studi pendahuluan ada perawat yang belum melakukan cuci tangan sesuai prosedur yang ditetapkan RS. Perawat memiliki andil yang sangat besar terhadap terjadinya infeksi nosokomial karena perawat merupakan tenaga kesehatan yang paling banyak melakukan kontak dengan pasien dan berinteraksi secara langsung dengan pasien selama 24 jam. Hasil penelitian kepatuhan petugas di rawat inap lebih rendah dibandingkan dengan bagian lain. Penelitian ini dilakukan untuk mengkaji tingkat kepatuhan perawat di ruang rawat inap RS dalam penerapan hand hygiene, serta faktor apa yang mempengaruhinya.

\section{METODE}

Jenis studi ini adalah deskriptif observasional dengan target populasi perawat yang bekerja di unit rawat inap rumah sakit 65 orang. Teknik pengambilan sampel dengan proportional stratified random sampling $80 \%$ sehingga didapatkan sampel sebanyak 54 orang.

Kepatuhan mencuci tangan didefinisikan subjek penelitian melakukan cuci tangan pada 5 momen secara keseluruhan dengan benar, dan dinilai dengan lembar observasi yang diadopsi dari WHO. Alat pengumpulan data yang digunakan adalah lembar observasi untuk mengukur perilaku, kuisioner untuk mengukur faktor yang mempengaruhi, kemudian dilakukan wawancara dan fokus grup diskusi dengan perawat, kepala ruang rawat inap dan tim PPIRS. Peneliti melakukan observasi selama 3 minggu mulai tanggal 10 Oktober sampai 31 Oktober 2013. Setiap subjek di observasi pada setiap momen di tiap ruang rawat inap yang berjumlah 6 ruang.

Pembagian kuesioner dilakukan kepada perawat ruang rawat inap sejumlah 54 orang untuk mengetahui pengetahuan perawat. Untuk menguji pengetahuan tentang 5 momen hand hygiene digunakan kuesioner yang telah diuji validitasnya dan diuji reliabilitas dengan skor pengetahuan diklasifikasikan dengan rumus Arikunto.

Wawancara dilakukan kepada beberapa perawat untuk mengetahui alasan tidak melakukan hand hygiene. Focus group discusion (FGD) dilakukan untuk menentukan akar masalah dengan menggunakan diagram fishbone (4) dan pemilihan solusi dengan pendekatan Urgency Seriousness Growth, fokus kajian adalah mengapa perawat tidak melakukan hand hygiene. FGD dilakukan di ruang pertemuan rumah sakit dihadiri oleh 10 orang yang terdiri dari kepala ruang rawat inap, tim PPIRS yang terdiri dari perawat pengendali infeksi rumah sakit dan perawat pengendali infeksi ruang rawat inap.

\section{HASIL}

Berdasarkan observasi terhadap 54 perawat ruang rawat inap didapatkan 135 kesempatan yang mengindikasikan hand hygiene, hanya 47 prosedur hand hygiene yang dilaksanakan, sehingga keseluruhan angka hand hygiene yang didapatkan adalah sebesar $35 \%$. Kepatuhan tertinggi ditemukan pada mencuci tangan sesudah kontak dengan cairan tubuh pasien, sedangkan kepatuhan terendah adalah sebelum kontak dengan pasien.

Tabel 1. Angka kepatuhan berdasarkan indikasi lima momen hand hygiene perawat rawat inap

\begin{tabular}{lcccccccc}
\hline $\begin{array}{c}\text { Indikasi Lima Moment } \\
\text { Hand Hygiene }\end{array}$ & \multicolumn{6}{c}{ Angka Kepatuhan di Ruang Rawat inap } \\
\cline { 2 - 7 } & A & B & C & D & E & F & Rerata \\
\hline $\begin{array}{c}\text { 1. Sebelum kontak } \\
\text { dengan pasien }\end{array}$ & $0 \%$ & $0 \%$ & $0 \%$ & $0 \%$ & $0 \%$ & $11 \%$ & $4 \%$ \\
$\begin{array}{c}\text { 2. sebelum tindakan } \\
\text { aseptik / invasif }\end{array}$ & $100 \%$ & $50 \%$ & $22 \%$ & $20 \%$ & $0 \%$ & $30 \%$ & $27 \%$ \\
$\begin{array}{c}\text { 3. setelah kontak dengan } \\
\text { cairan tubuh pasien }\end{array}$ & $67 \%$ & $67 \%$ & $67 \%$ & $67 \%$ & $67 \%$ & $67 \%$ & $67 \%$ \\
$\begin{array}{c}\text { 4. sesudah kontak dengan } \\
\text { pasien }\end{array}$ & $100 \%$ & $50 \%$ & $22 \%$ & $20 \%$ & $0 \%$ & $30 \%$ & $27 \%$ \\
$\begin{array}{c}\text { 5. Setelah kontak dengan } \\
\text { benda lingkungan } \\
\text { sekitar pasien }\end{array}$ & $50 \%$ & $50 \%$ & $29 \%$ & $60 \%$ & $100 \%$ & $64 \%$ & $56 \%$ \\
\hline
\end{tabular}


Berdasarkan kuisioner tentang hand hygiene diperoleh hasil bahwa sebanyak $64 \%$ perawat mempunyai pengetahuan kurang, $32 \%$ perawat mempunyai pengetahuan cukup dan $4 \%$ perawat mempunyai pengetahuan baik. Hasil observasi juga menunjukkan semua ruang mempunyai fasilitas sarana dan prasarana hand hygiene yang lengkap. Fasilitas hand hygiene yang ada di tempat observasi terdiri dari 2 jenis sarana, yaitu wastafel yang dilengkapi dengan sabun antimikroba dan alkohol gliserin untuk handrub. Hanya saja semua ruang belum dilengkapi dengan poster prosedur hand hygiene.

\section{Tabel 2. Sarana dan prasarana hand hygiene di ruang} rawat inap

\begin{tabular}{lcccccc}
\hline \multirow{2}{*}{ Jumlah Fasilitas } & \multicolumn{7}{c}{ Ruang Rawat Inap } \\
\cline { 2 - 7 } & A & B & C & D & E & F \\
\hline Tersedia wastafel & 1 & 1 & 1 & 1 & 1 & 1 \\
Air bersih mengalir & 1 & 1 & 1 & 1 & 1 & 1 \\
Tersedia Sabun cair & 1 & 1 & 1 & 1 & 1 & 1 \\
Tersedia handuk bersih & 1 & 1 & 1 & 1 & 1 & 1 \\
\& kering & 1 & 1 & 1 & 1 & 1 & 1 \\
Tersedia handrup & 1 & 1 & 1 & 1 & 1 & 1 \\
Wastafel bersih & 1 & 1 & 1 & 1 & 1 & 1 \\
Tempat handuk kotor & 0 & 0 & 0 & 0 & 0 & 0 \\
$\quad$ Tersedia poster 5 & & & & & & \\
$\begin{array}{l}\text { moment hand hygiene } \\
\text { Tersedia poster } \\
\text { prosedur hand hygiene }\end{array}$ & 0 & 0 & 1 & 0 & 1 & 0 \\
$\quad$ Tersedia SPO hand & & & & & & \\
hygiene & 1 & 1 & 1 & 1 & 1 & 1 \\
\hline
\end{tabular}

Keterangan: 0 artinya tidak ada, 1 artinya tersedia

Untuk mencari faktor potensial yang berpengaruh terhadap kepatuhan hand hygiene perawat ruang rawat inap dilakukan fokus grup diskusi bersama kepala ruangan dan tim PPIRS. Identifikasi akar masalah dengan menggunakan diagram fishboneberdasarkan padaman, machine, method, material dari pengamatan, wawancara, dan brainstorming, disajikan pada Gambar 1.

\section{Fishbone diagram.}

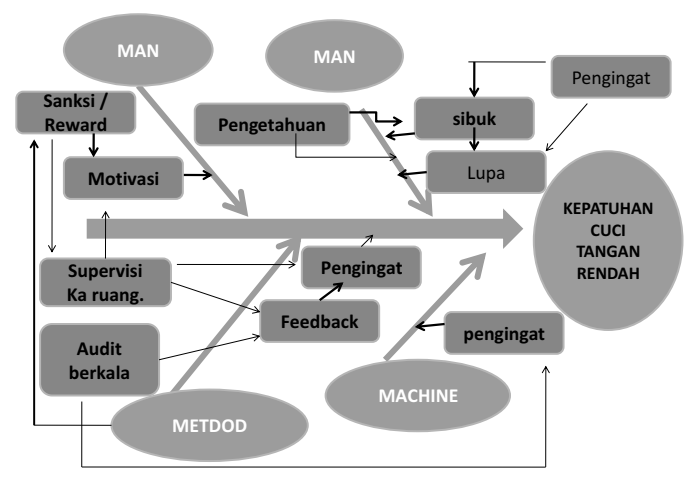

Gambar 1. Fishbone diagram faktor potensial penyebab rendahnya kepatuhan hand hygiene perawat ruang rawat inap

Pada aspek pelaksana (man), pengetahuan perawat tentang hand hygiene masih kurang. Pada aspek peralatan dan aspek material untuk pelaksanaan hand hygiene, menunjukkan ketersediaan dan kemudahan akses fasilitas hand hygiene sudah baik. Pada aspek metode didapatkan kebijakan, pedoman dan SPO hand hygiene sudah ada, program audit khusus untuk hand hygiene belum ada sehingga tidak dapat dilakukannya evaluasi secara berkala dan umpan balik pelaksanaan hand hygiene, sistem belum ada, sistem pengingat disini adalah dalam bentuk poster, teks berjalan di layar TV rumah sakit, supervisi kepala ruangan tentang pelaksanaan hand hygiene dan sesama perawat mengingatkan bila ada yang lupa melakukan hand hygiene. Kebijakan rumah sakit yang mengatur tentang pemberian sanksi atau penghargaan terhadap pelaksanaan hand hygiene belum ada. Pada diagram fishbone terlihat adanya gap yang cukup nyata pada aspek metode, aspek pelaksana dan aspek peralatan. Akar masalah rendahnya tingkat kepatuhan hand hygiene perawat ruang rawat inap adalah belum terlaksananya audit hand hygiene dalam dua tahun terakhir, tidak ada penghargaan atau sanksi bagi pelaksana hand hygiene, kurangnya pengetahuan perawat tentang hand hygiene dan kurangnya peralatan pengingat untuk melakukan hand hygiene.

Identifikasi alternatif solusi dilakukan dengan mengidentifikasi semua kemungkinan solusi yang dapat dilakukan pada tiap level akar masalah, dengan tujuan untuk menghilangkan, mengendalikan dan mendeteksi permasalahan. Metode untuk menemukan alternatif solusi yang dipakai adalah metode Urgency Seriousness Growth (USG). Dari perhitungan USG didapatkan alternatif solusi yang dipilih adalah pembuatan program audit hand hygiene.

Tabel 4. Hasil perhitungan USG untuk pemilihan alternatif solusi

\begin{tabular}{clcccc}
\hline NO & \multicolumn{1}{c}{ Alternatif Solusi } & Urgent & Severe & Growth & Total \\
\hline 1 & $\begin{array}{l}\text { Refreshing diklat hand } \\
\text { hygiene }\end{array}$ & 29 & 31 & 34 & 94 \\
2 & $\begin{array}{l}\text { Program Audit hand } \\
\text { hygiene }\end{array}$ & 34 & 36 & 37 & 107 \\
3 & Ada Sanksi / Reward & 26 & 32 & 33 & 91 \\
4 & Ada pengingat & 32 & 34 & 40 & 106 \\
\hline
\end{tabular}

\section{DISKUSI}

Hasil pengamatan menunjukkan bahwa secara keseluruhan tingkat kepatuhan perawat di ruang rawat inap RSIA dalam melakukan hand hygiene yaitu 35\%. Hal ini sesuai dengan penelitian Pitted yang menunjukkan tingkat kepatuhan petugas kesehatan dalam melakukan hand hygiene masih $<50 \%$ (5). Sebuah penelitian pada 40 rumah sakit melaporkan kepatuhan tenaga kesehatan yang melakukan hand hygiene sebelum dan setelah ke pasien bervariasi antara $24 \%$ sampai $89 \%$ (rata-rata 56,6\%). Menurut data Riset Kesehatan Dasar tahunan prevalensi nasional berperilaku benar dalam cuci tangan adalah $23,2 \%(3)$.

Bila dilihat dari indikasi 5 momen hand hygiene perawat mengabaikan hand hygiene sebelum kontak dengan pasien (4\%). Perawat kurang menyadari bahwa tangan mereka dapat membuat pasien terkontaminasi kuman dari tindakan sebelumnya setelah menyentuh pasien sebelumnya atau barang disekitar pasien. Penelitian 
Casewell menemukan bahwa $17 \%$ perawat di ICU terkontaminasi tangannya oleh 100-1000 CFUs Klebsiella setelah melakukan aktivitas yang bersih seperti memeriksa tekanan darah, nadi, suhu, menyentuh tangan atau bahu pasien (6).

Ada dua faktor yang mempengaruhi perilaku petugas kesehatan terhadap kepatuhan mencuci tangan yaitu faktor personal dan faktor lingkungan (7). Faktor personal yang dapat mempengaruhi antara lain adalah pengetahuan tentang mencuci tangan $(5,7)$, pernah mengikuti seminar tentang infeksi nosokomial, pengetahuan tentang proses perjalanan infeksi (7). Faktor lingkungan yang dapat mempengaruhi perilaku mencuci tangan antara lain, kurangnya fasilitas hand hygiene (5), komite pengendalian infeksi, evaluasi terhadap perilaku petugas kesehatan terhadap kepatuhan mencuci tangan, kurang tenaga dan pasien yang banyak atau overcrowding, iritasi kulit dan kurang komitmen dari institusi tentang hand hygiene yang baik $(5,7)$.

Salah satu faktor yang mempengaruhi tingkat kepatuhan petugas kesehatan dalam melakukan hand hygiene adalah kurangnya pengetahuan tentang praktek hand hygiene sesuai dengan standar (5). Faktor lain adalah kurangnya pengetahuan akan pentingnya melakukan hand hygiene dalam mengurangi penyebaran bakteri dan mencegah terjadinya kontaminasi pada tangan.

Hasil analisis terhadap pengetahuan perawat tentang hand hygiene melalui jawaban kuisioner didapatkan bahwa 36 orang perawat (64\%) pengetahuannya masih kurang. Melihat dari beberapa item kuisioner yang diisi perawat menunjukkan perawat belum terpapar dengan semua pertanyaan yang diajukan. Berdasarkan hasil focus group discussion, pengetahuan yang masih kurang disebabkan ada beberapa perawat yang belum pernah mendapat pendidikan dan pelatihan tentang hand hygiene dalam satu tahun terakhir. Beberapa perawat mengatakan pernah mendapatkan pendidikan dan pelatihan namun lupa. Kemungkinan lain penyebab kurangnya pengetahuan tentang hand hygiene karena perawat masih kurang terpapar dengan informasi tentang hand hygiene yang update dan ilmiah. Hasil observasi menunjukkan faktor kesibukan perawat dalam melakukan kegiatan rutinitas keperawatan di ruang rawat inap berperan dalam kepatuhan cuci tangan.

Perilaku yang didasarkan pengetahuan akan lebih langgeng daripada perilaku yang tidak didasari oleh pengetahuan. Perawat dengan tingkat pengetahuan yang baik tentang cuci tangan menunjukkan kepatuhannya melakukan cuci tangan. Hal ini sesuai dengan hasil penelitian Saragih dan Rumapea bahwa perawat dengan tingkat pengetahuan yang baik tentang cuci tangan mempunyai kepatuhan yang lebih tinggi $(73,75 \%)$ untuk melakukan prosedur cuci tangan (8). Program sosialisasi cuci tangan dengan cara memberikan pendidikan tentang pengetahuan 5 momen cuci tangan dapat meningkatkan pengetahuan dan kepatuhan cuci tangan 5 momen pada para perawat yang bekerja di unit perawatan intensif (3). Peningkatan kepatuhan cuci tangan ini sesuai dengan peningkatan pengetahuan, yaitu sebelum sosialisasi hanya sekitar $80 \%$ perawat yang mengetahui kepentingan dan prosedur cuci tangan dan setelah sosialisasi kepatuhan cuci tangan meningkat menjadi $100 \%$. Hal ini menunjukankan bahwa proses sosialisasi untuk meningkatkan pengetahuan petugas kesehatan dapat meningkatkan tingkat kepatuhan cuci tangan. Kurangnya pengetahuan merupakan salah satu hambatan untuk melakukan hand hygiene sesuai rekomendasi (9). Diperlukan suatu program pendidikan tentang hand hygiene yang berkelanjutan dengan informasi yang selalu diperbarui.

Dari hasil observasi dan wawancara tentang kelengkapan fasilitas hand hygiene yang disediakan di ruang rawat Inap tersedia dengan baik. Fasilitas yang disediakan dimasingmasing ruangan dilengkapi dengan wastafel, air bersih yang mengalir lancar, sabun antimikroba dan alkohol gliserin untuk hand rub. Ketersediaan sabun dirasa cukup dan tersedia dalam bentuk sabun cair antiseptik. Pengering cuci tangan tersedia dalam bentuk lap sekali pakai. Persediaan lap mendekati pergantian tugas pada beberapa ruang rawat inap sudah habis, dan menunggu petugas house keeping shift berikutnya untuk menyediakan lap, ruang rawat inap memberikan solusi dengan menggunakan tissue sebagai pengganti selama lap belum ada. Kelengkapan fasilitas yang disediakan untuk hand hygiene di ruang rawat Inap tersedia dengan baik, namun tingkat kepatuhan melakukan hand hygiene masih rendah (35\%). Hasil penelitian ini bertentangan dengan hasil penelitian yang dilakukan oleh Pitted menyatakan bahwa salah satu kendala dalam ketidakpatuhan terhadap hand hygiene adalah sulitnya mengakses tempat cuci tangan atau persediaan alat lainnya yang digunakan untuk melakukan hand hygiene. Kemudahan dalam mengakses persediaan alat-alat untuk melakukan hand hygiene, bak cuci tangan, sabun atau alkohol jell adalah sangat penting untuk membuat kepatuhan menjadi optimal sesuai standar.

Berdasarkan wawancara dengan tim PPIRS menyatakan bahwa ada kebijakan Rumah Sakit yang menetapkan implementasi hand hygiene berdasar panduan hand hygiene dari WHO. Hampir seluruh perawat yang diamati di ruang rawat inap mengetahui adanya prosedur hand hygiene yang di dalamnya sudah dirasa efektif untuk dijalankan, dan tiap langkah dalam panduan tersebut dimengerti.

Hasil observasi di tiap ruang rawat inap belum ditemukan poster pengingat lima momen indikasi hand hygiene. Poster pengingat petunjuk yang benar dalam melakukan hand hygiene sudah tersedia tetapi jumlahnya kurang karena hanya ada di dua ruang nurse station. Hal ini dapat menjadi penghambat perawat dalam melakukan hand hygiene, karena perawat lupa akan indikasi dan teknik atau standar hand hygiene.

Berdasarkan fokus grup diskusi di dapatkan bahwa belum ada kebijakan rumah sakit untuk memberikan konsekuensi kepada petugas yang tidak melakukan hand hygiene, dan memberikan penghargaan kepada petugas yang melakukan hand hygiene. Dengan adanya penghargaan dapat memberikan motivasi terhadap anggota organisasi, dari motivasi tinggi tersebut dapat memberikan hasil yang lebih dari yang diharapkan dalam organisasi. Hukuman berperan penting dalam memelihara kedisiplinan pegawai. Dengan hukuman maka pegawai akan takut untuk melanggar peraturan-peraturan perusahaan, tidak melakukan kesalahan yang merugikan dan mengurangi resiko kesalahan dalam organisasi (10). Penerapan pemberian hukuman dan penghargaan dapat membawa pengaruh positif antara lain adanya tolok ukur kinerja yang jelas, kinerja individu semakin meningkat karena adanya sistem pengawasan yang obyektif.

Berdasarkan hasil fokus grup diskusi didapatkan bahwa 
selama satu tahun terakhir belum dilakukan evaluasi kepatuhan hand hygiene, dan selama ini mereka tidak pernah mendapatkan umpan balik pelaksanaan hand hygiene di unit masing masing. Standar akreditasi RS tahun 2012 menyatakan bahwa rumah sakit mengembangkan suatu pendekatan untuk mengurangi risiko infeksi yang terkait pelayanan kesehatan. Penjabaran dari standar itu adalah penerapan program cuci tangan. Program tersebut harus merujuk pada pedoman yang diterima secara internasional; misalnya dari WHO atau CDC. Rumah sakit harus mengadopsi pedoman cuci tangan dari salah satu lembaga tersebut, membuat kebijakan dan prosedur lengkap perihal cuci tangan, serta memastikan penerapan yang konsisten di seluruh area rumah sakit.

Untuk memastikan konsistensi pelaksanaan program hand hygiene, harus dilakukan pemantauan dan pengukuran tingkat keberhasilan pelaksanaannya, evaluasi tingkat keberhasilan serta tindak lanjut. Berdasarkan hal tersebut perlu disusun program audit hand hygiene. Pengertian audit hand hygiene adalah melakukan pemeriksaan praktek aktual terhadap kepatuhan sesuai dengan program dan standar PPIRS yang sudah dibuat. Berdasarkan hasil fokus grup diskusi disepakati pokok kegiatan dalam program audit hand hygiene yaitu sosialisasi program dan refreshing pengetahuan tentang hand hygiene sebelum pelaksanaan audit, pelaksanaan audit hand hygiene dan fasilitas hand hygiene di seluruh ruang rawat inap, dan pemberian umpan balik hasil audit kepada perawat setelah pelaksanaan audit hand hygiene.

Menurut WHO untuk meningkatkan kepatuhan dalam melakukan hand hygiene diperlukan multidimensi strategi pendekatan (9). Pendekatan tersebut meliputi perubahan sistem dengan menyediakan hand rub berbasis alkohol selain wastafel dan sabun antiseptik di setiap titik perawatan, pendidikan dan pelatihan kepada petugas kesehatan secara teratur dan berkala, evaluasi dan umpan balik berupa monitoring, evaluasi dan pemberian umpan balik pelaksanaan dan infra struktur hand hygiene, persepsi dan pengetahuan petugas kesehatan secara teratur, adanya pengingat di tempat kerja untuk promosi dan meningkatkan kepedulian petugas kesehatan. Upaya tersebut harus ditunjang dengan dukungan organisasi dan partisipasi pasien untuk meningkatkan budaya keselamatan. Hasil penelitian Benedetta et al di Afrika menunjukkan dengan mengimplementasikan strategi dari WHO tersebut, dapat meningkatkan kepatuhan hand hygiene para petugas kesehatan sebesar $8 \%$ dari $21,8 \%$ (11). Kunci keberhasilan hand hygiene berasal dari berbagai intervensi yang melibatkan perubahan perilaku, pendidikan kreatif, monitoring dan evaluasi, dan lebih penting adalah keterlibatan supervisor sebagai rolemodel serta dukungan pimpinan (1).

Agar pelaksanaan program audit hand hygiene dapat terlaksana dengan baik diperlukan dukungan keterlibatan kepala ruangan selaku pimpinan dari perawat pelaksana di masing-masing ruang rawat inap. supervisi merupakan bagian dari fungsi directing (penggerakkan/pengarahan) dalam fungsi manajemen yang berperan untuk

\section{DAFTAR PUSTAKA}

1. Departemen Kesehatan Republik Indonesia. Pedoman Manajerial Pencegahan dan Pengendalian Infeksi di Rumah Sakit dan Fasilitas Pelayanan mempertahankan agar segala kegiatan yang telah diprogramkan dapat dilaksanakan dengan benar dan lancar (12). Supervisi secara langsung memungkinkan manajer keperawatan menemukan berbagai hambatan/permasalahan dalam pelaksanaan asuhan keperawatan di ruangan dengan mengkaji secara menyeluruh faktor-faktor yang mempengaruhinya dan bersama dengan staf keperawatan untuk mencari jalan pemecahannya (13).

Tujuan pokok dari supervisi ialah menjamin pelaksanaan berbagai kegiatan yang telah direncanakan secara benar dan tepat, dalam arti lebih efektif dan efesien, sehingga menghasilkan kinerja yang baik dan tujuan yang telah ditetapkan organisasi dapat dicapai dengan memuaskan (14). Kepala ruangan melakukan evaluasi perawat pelaksana dengan memberikan umpan balik baik formal maupun informal untuk meningkatkan kinerja perawat pelaksana. Perhatian, rasa peduli dan tanggung jawab untuk memberikan umpan balik bagi perawat pelaksanasangat perlu dilakukan kepala ruangan untuk meningkatkan mutu asuhan keperawatandan program patient safety (13).

Hasil penelitian Maria menunjukkan ada hubungan peran kepala ruangan melakukan supervisi perawat pelaksana dengan penerapan patient safety, dengan adanya supervisi yang maksimal perawat pelaksana melakukan penerapan patient safety dengan baik. Supervisi kepala ruangan yang dilakukan perawat di rumah sakit menunjukkan perawat pelaksana telah melakukan kinerja sesuai dengan perencanaan yang telah dibuat oleh kepala ruang di ruangan sehingga kepatuhan terhadap SPO mencuci tangan bisa mencapai $100 \%$ (13). Hasil penelitian oleh Damanik menunjukkan bahwa adanya pengawasan terhadap pelaksanaan hand hygiene lebih banyak patuh melakukan hand hygiene (15). Arifien menunjukkan bahwa responden yang mendapat dukungan dari pimpinannya berpeluang lebih patuh sebesar 21 kali dibandingkan dengan responden yang kurang mendapat dukungan dari pimpinannya. Selain itu hasil juga menunjukkan bahwa ada hubungan yang bermakna antara dukungan/komitmen pimpinan dengan kepatuhan (15).

Berdasarkan pengamatan kepatuhan hand hygiene perawat ruang rawat inap rumah sakit masih rendah (35\%). Kepatuhan hand hygiene perawat lebih banyak dilakukan sesudah perawat melakukan tindakan invasif aseptik, dan paling sedikit dilakukan sebelum perawat kontak dengan pasien. Tingkat pengetahuan perawat sebagian besar (64\%) masih kurang. Faktor potensial yang berhubungan dengan kepatuhan hand hygiene adalah pengetahuan perawat yang kurang, tidak adanya pelaksanaan audit hand hygiene secara berkala yang diketahui perawat, dan tidak ada supervisi kepala ruang terhadap pelaksanaan hand hygiene di ruang rawat inap rumah sakit.

Hasil penelitian ini menunjukkan bahwa kepatuhan hand hygiene pada perawat secara umum masih rendah terutama pada fase sebelum kontak maupun tindakan. Kurangnya pengetahuan, dan penguat dalam bentuk pengingat, audit, mekanisme reward punishment menjadi akar masalah rendahnya kepatuhan hand hygiene.

Kesehatan Lainnya. Jakarta: Departemen Kesehatan $\mathrm{Rl} ; 2008$.

2. Roeshadi D dan Winarti A. Pengendalian Infeksi Nosokomial di RSUD dr Soetomo Surabaya. Cermin 
Kedokteran Indonesia. 1993; 82: 13-15.

3. Jamaludidin J, Sugeng S, Wahyu I, dan Sondang M. Kepatuhan Cuci Tangan 5 Momen di Unit Perawatan Intensif. Majalah Kedokteran Terapi Intensif. 2012; 2(3): $125-129$.

4. Ilie G and Ciocoiu C. Application of Fishbone Diagram to Determine the Risk of an Event with Multiple Causes. Management Research and Practice. 2010; 2(1): 1-20.

5. Pittet D. Improving Adherence to Hand Hygiene Practice: A Multidisciplinary Approach. Emerging Infectious Diseases. 2011; 7(2): 234-240.

6. Casewell $M$ and Philips I. Hand as a Route of Transmission or Klebsiella Species. British Medical Journal. 1977; 2(6098): 1315-1317.

7. Takahashi I and Turale S. Evaluation of Individual and Facility Factors that Promote Hand Washing in AgedCare Facilities In Japan. Nursing \& Health Sciences. 2010; 12(1): 127-134.

8. Saragih R dan Rumapea N. Hubungan Karakteristik Perawat dengan Tingkat Kepatuhan Perawat Melakukan Cuci Tangan di Rumah Sakit Columbia Asia Medan. (Online). http://uda.ac.id/jurnal/main.php? page $=$ view $\& \& i d=89$.

9. WHO. Using WHO Hand Hygiene Improvement Tools to Support the Implementation of National/SubNational Hand Hygiene Campaigns. (Online) 2010. http:// www.who.int/gpsc/national_campaigns /PS_hand_hygiene_tools_2010_6_en.pdf

10. Yiswi N. Imbalan dan Hukuman dalam Organisasi. ( O n I i n e ) 2013 . http://17111512.student.gunadarma.ac.id/tulisan.ht $\mathrm{ml}$

11. Allegranzi B, Sax $H$, Richet $H$, et al. Successful Implementation of the World Health Organization Hand Hygiene Improvement Strategy in a Referral Hospital in Mali, Africa Infection Control and Hospital Epidemiology. Infection Control and Hospital Epidemiology. 2010; 31(2): 133-141.

12. Suarli S dan Bahtiar Y. Manajemen Keperawatan dengan Pendekatan Praktis. Jakarta: Erlangga; 2010.

13. Rumampuk MVH, Budu, dan Nontji W. Peran Kepala Ruangan Melakukan Supervisi Perawat dengan Penerapan Patient Safety di Ruang Rawat Inap Rumah Sakit. [Tesis]. Universitas Hasanudin, Makasar. 2013.

14. Anwar AA, Irwandy, dan Noer BN. Hubungan Pengetahuan, Motivasi, dan Supervisi dengan Kinerja Perawat dalam Melaksanakan Patient Safety Di RSUP dr. Wahidin Sudirohusodo Tahun 2012. [Tesis]. Universitas Hasanudin, Makasar. 2012

15. Damanik SM, Susilaningsih FS, dan Amrullah AA. Kepatuhan Hand Hygiene di Rumah Sakit Immanuel Bandung. [Tesis]. Universitas Padjajaran, Bandung. 2011. 